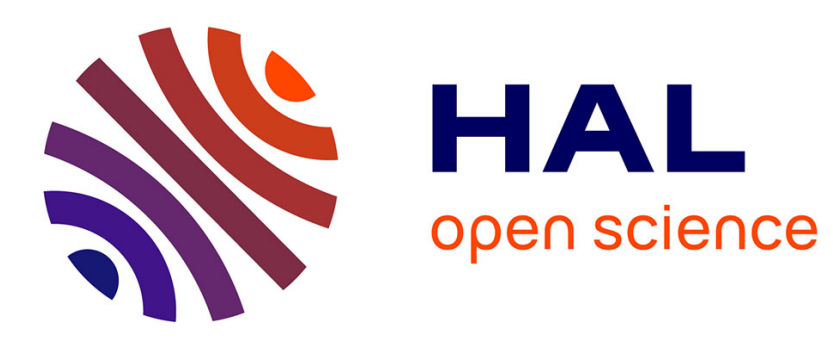

\title{
On the asymmetrical but regular properties of French possessive DPs \\ Anne Zribi-Hertz
}

\section{To cite this version:}

Anne Zribi-Hertz. On the asymmetrical but regular properties of French possessive DPs. From NP to DP: the expression of possession in noun phrases, 2 (5), John Benjamins, pp.141-163, 2003, Linguistics today. halshs-00107306

\section{HAL Id: halshs-00107306 https://shs.hal.science/halshs-00107306}

Submitted on 17 Oct 2006

HAL is a multi-disciplinary open access archive for the deposit and dissemination of scientific research documents, whether they are published or not. The documents may come from teaching and research institutions in France or abroad, or from public or private research centers.
L'archive ouverte pluridisciplinaire HAL, est destinée au dépôt et à la diffusion de documents scientifiques de niveau recherche, publiés ou non, émanant des établissements d'enseignement et de recherche français ou étrangers, des laboratoires publics ou privés. 
Anne Zribi-Hertz

UMR 7023, CNRS/Université Paris 8

[In M. Coene \& Y. D'Hulst (eds), 2003, From NP to DP, volume 2: The Expression of

Possession in Noun Phrases [Linguistik Aktuell / Linguistics Today 56], 141-163.

Amsterdam-Philadelphia: John Benjamins Publishing Company]

\section{On the asymmetrical but regular properties of French possessive DPs}

\section{Introduction}

\subsection{Possessive DPs as predicative DPs}

This paper will be concerned with so-called possessive DPs, which involve two main constituents known as Possessor and Possessee - two terms I shall be using below for tradition's sake:

\begin{tabular}{|c|c|c|}
\hline English & $\begin{array}{l}\text { John 's } \\
\text { POSSESSOR }\end{array}$ & $\begin{array}{l}\text { book } \\
\text { POSSESSEE }\end{array}$ \\
\hline French & $\begin{array}{ll}\text { le livre } \\
\quad \text { POSSESSEE }\end{array}$ & $\begin{array}{ll}\text { de } & \text { Jean } \\
& \text { POSSESSOR }\end{array}$ \\
\hline
\end{tabular}

I will however assume, following Chomsky (1972), Szabolcsi (1984, 1994), Abney (1987), Kayne (1993, 1994), Borer (1996), Kihm (1998), Zribi-Hertz (1998, 1999), and others, that possessive DPs are predicative DPs, i.e., DPs which include a subject located outside the existential-closure domain (cf. Carlson, this volume). That the socalled Possessor should be analysed as a subject is immediately clear in the classical English examples (2) :
a. John criticised
this book.
(predicative clause)
b. John's criticism of this book. (predicative DP = 'possessive DP')

English, exemplified in (2), is not the only language where the symmetry is straightforward. As shown by Szabolcsi (1984, 1994) and Knittel (1997), Hungarian possessors are constructed as subjects; as shown by Zribi-Hertz \& Adopo (1992), Attie possessors are constructed as subjectsP; as shown for instance by Voskuil (1993) or Paul (1996), Malagasy possessors are constructed as demoted subjects: 
(3) Hungarian

SUBJECT

a.

(én) szeret $\quad \varnothing \quad$-em ...

1sg love PRS 1sg

'I love... (+indefinite object)'

b.

János szeret $\quad \varnothing \quad \varnothing \ldots$

John love PRS 3sg

(finite clause)

'John loves... (+indefinite object)'

c. a(z) (én) haz -a $\varnothing \quad-m$

DF 1sg house 'poss' sg 1sg

d. a János haz -a $\varnothing \quad \varnothing$

DF John house 'poss' sg 3sg

'John's house'

[adapted from Knittel 1998]

(4) Attie $^{2}$

a.

SUBJECT

$\Downarrow$

Apo ó fœ.

Apo 3ANsg+FUT fly away

'Apo will fly away.'

b.

$\begin{array}{lll}\text { Apo ó } & \text { kwe - } \varepsilon & \\ \text { Apo 3ANsg } & \text { house DFsg } & \text { (possessive DP) } \\ \text { 'Apo's house' } & & \end{array}$

(5) Malagasy

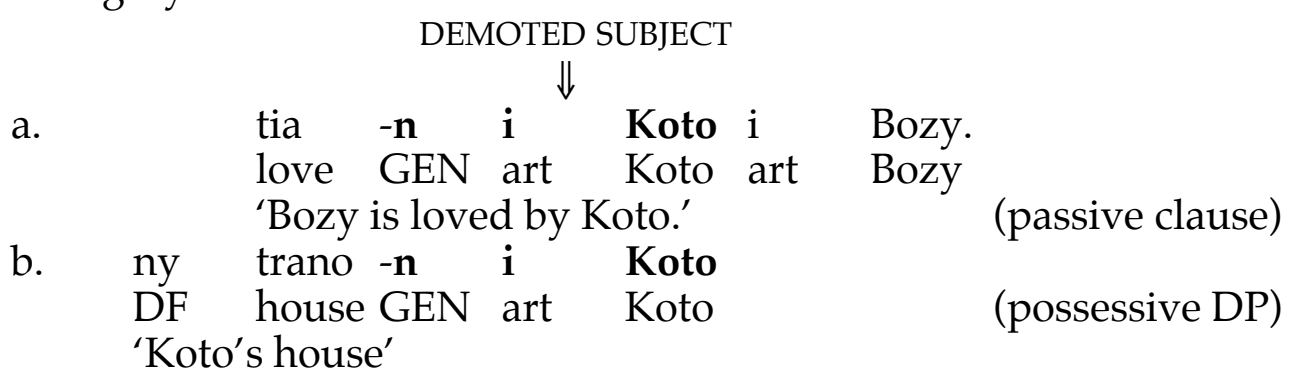

\footnotetext{
${ }^{1}$ Abbreviations used in the glosses and trees: 1, 2, $3=$ first, second, third person; $\mathrm{AN}=$ animate; art $=$ article (an expletive determiner occurring with human names, in Malagasy); $\mathrm{DAT}=$ dative Case; $\mathrm{DF}=$ definite; $-\mathrm{df}=$ minus definite; $\mathrm{F}(\mathrm{EM})=$ feminine gender; $\mathrm{FUT}$ = future tense; $\mathrm{GEN}$ = genitive Case; $\mathrm{M}=$ masculine gender; $\mathrm{pl}=$ plural; $\mathrm{PRS}=$ present tense; $\mathrm{sg}=$ singular; $\mathrm{S}=$ English 'possessive' marker.

${ }^{2}$ Attie is a Kwa language spoken in the Ivory Coast.
} 


\subsection{The core structure of possessive DPs}

One way to represent this regular pattern is to assume that all possessive DPs involve the same core set of projections. The structure sketched in (6) could be a common denominator for the representation of possessive DPs : ${ }^{3}$

(6)

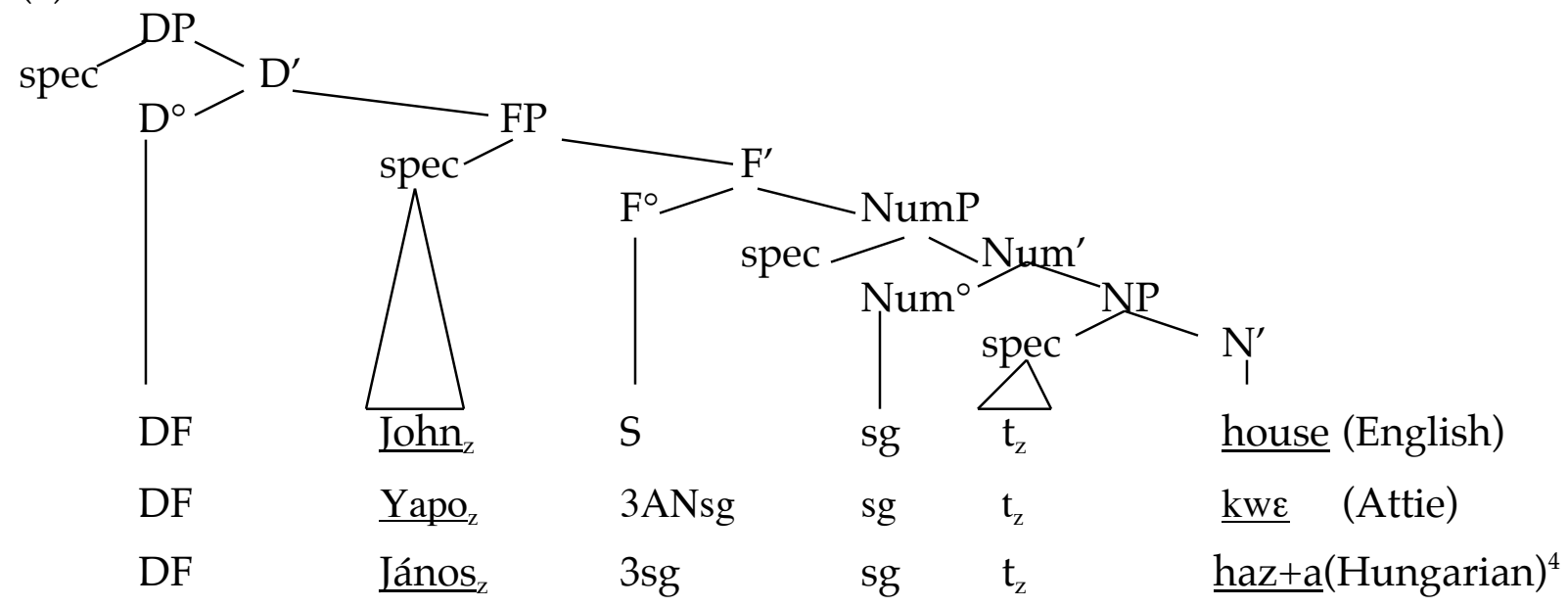

For the three languages considered in (6), the assumption that noun phrases are dominated by a DP projection seems straightforward; in some languages (e.g. English) the 'definite feature' in D, which might boil down to a universal quantifier (Milsark 1977), has a vacuous spell-out in possessive DPs. The FP projection provides a landing site for the subject; the F head contains a Person feature in some languages (Hungarian, Attie), but not in all: I depart here from Kayne $(1993,1994)$ in assuming the English 'possessive' affix to spell out a relational feature distinct from Person (evidence for this is given in Zribi-Hertz 1997). Following Collins (1997) and Chomsky (1999), I am also assuming in (6) that head-to-head movement occurs after syntax, in Morphology, and leaves no trace. In English and Attie, the noun raises up to Number; in Hungarian it further raises up to $\mathrm{F}^{\circ}$, where it inflects for Person. In a language such as Attie, we must further account for the fact that the definite marker occurs at the right periphery of the DP - an interesting but independent matter, which I shall leave aside here.

\section{Why does French look irregular?}

Under these general assumptions, we should expect French possessive DPs to be internally structured as nominal predications. In this language, however, possessive DPs look at first glance quite different from tensed predications, and thus do not appear as straightforwardly simple as their English counterparts. The examples in $\left(7^{\prime}\right)$ through $\left(9^{\prime}\right)$ illustrate the Standard-French pattern :
(7)a. I prefer Iohn's box.
(7')a. Je préfère la boîte de Jean.
b. I prefer $\underline{\text { hi }} \mathrm{s}$ box. b1. *Je préfère la boîte de $\underline{\text { lui. }}$. b2. Je préfère sa boîte.

\footnotetext{
3 Throughout this article, I treat 'definiteness' as a binary feature ( \pm definite), an assumption I am now convinced is not satisfactory. This matter is, however, not crucially relevant for the core issue raised here, which is the complementary distribution of lexical and functional possessors in Standard French.

${ }^{4}$ Knittel (1998) argues that the affix -a, which she labels 'possessive', indicates that the $\mathrm{N}$ has a theta-grid more precisely, that it licenses an external argument. Correlatively, it systematically occurs in 'possessive' DPs.
} 
(8)a. I found a box

b. I found a box of John's. of hi $\mathrm{s}$.

ø.

ø. $\left(8^{\prime}\right)$ a. * 'J'ai trouvé une boîte à Jean.

b. J'ai trouvé une boîte à lui.

$\left(9^{\prime}\right)$ a. Je préfère celle de Jean. b1. *Je préfère celle de lui. b2. Je préfère la sienne ø.

b. I prefer $\underline{h i} \mathrm{~s} \quad \varnothing$

A common view concerning the contrasts in (7)-(9) is that pronominal possessors, in French, crucially differ from lexical possessors in that they are special clitics, as are other personal argument markers, in this language (cf. Milner 1982b, Godard 1986, Giorgi \& Longobardi 1991, Tremblay 1991). Correlatively, they never surface in the same linear positions as lexical arguments.

However, this view is shown to be inaccurate by the contrast in $\left(8^{\prime}\right)$ : in this pair of examples, to which I shall return below, the pronoun is, crucially, nonclitic, but it occurs in a position where a lexical DP is disallowed. This suggests that the contrast between lexical and personal possessors, in French, does not boil down to cliticihood.

\section{Possessee Raising}

In the English examples (7) through (9), lexical possessors (e.g. John) and pronominal possessors occur in the same position, which we may identify as spec,FP in the x-bar diagram (6).

In the French examples $\left(7^{\prime}\right)$ through $\left(9^{\prime}\right)$, lexical and pronominal possessors exhibit complementary distributions. In $\left(7^{\prime}\right.$ a) and $\left(9^{\prime} a\right)$, the lexical possessor occurs to the right of the possessee, which, French being an SVO language, seems to conflict with the generalization that possessors are subjects in DPs. Kayne $(1993,1994)$, however, puts forward an assumption which enables us to conciliate the facts in ( 7 'a) and (9'a) with pattern (6): his leading idea is that possessive DPs of the kind exemplified by $\left(7^{\prime} \mathrm{a}\right)$ are derived by a movement rule which 'relativizes' the Possessee, since it is similar to that which occurs in relativized DPs. Kayne's proposal is freely adapted in (10) below :

(10) la maison de Pierre

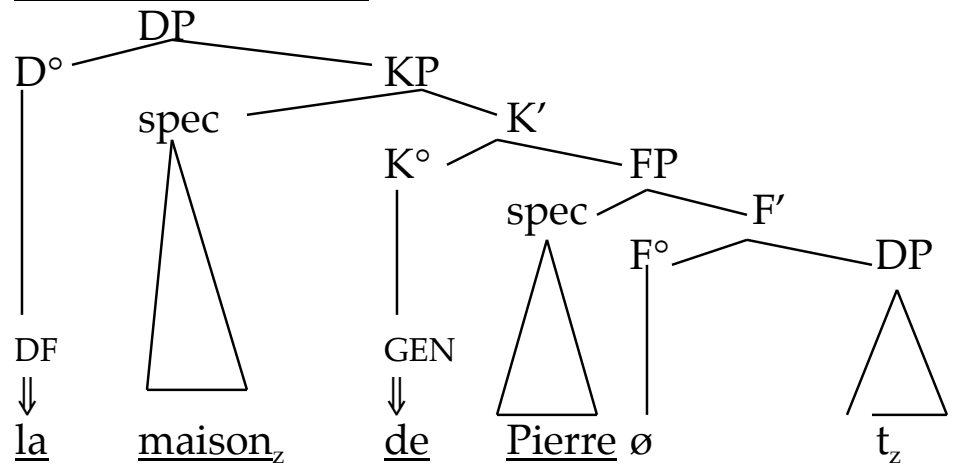


Compare (10) with (11), la maison que Pierre construit, 'the house which Pierre is building' :

$(11)$

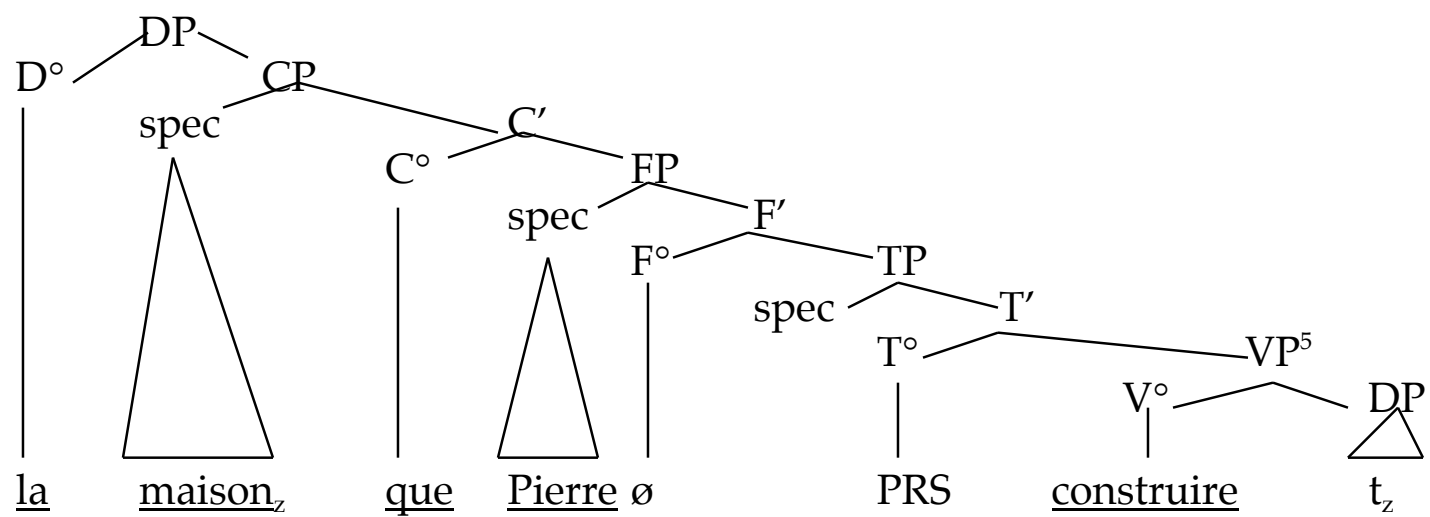

The possessive DP of (9'a), celle de Jean, may be derived in the same way as (10), if we assume that $\underline{\mathrm{c}(\mathrm{e})}$, in celle, spells out a feature generated in $\mathrm{D}^{\circ}$, while elle is the spell-out of a raised definite DP reduced to its functional features [definite, feminine, singular]. This is shown in (12):

(12)

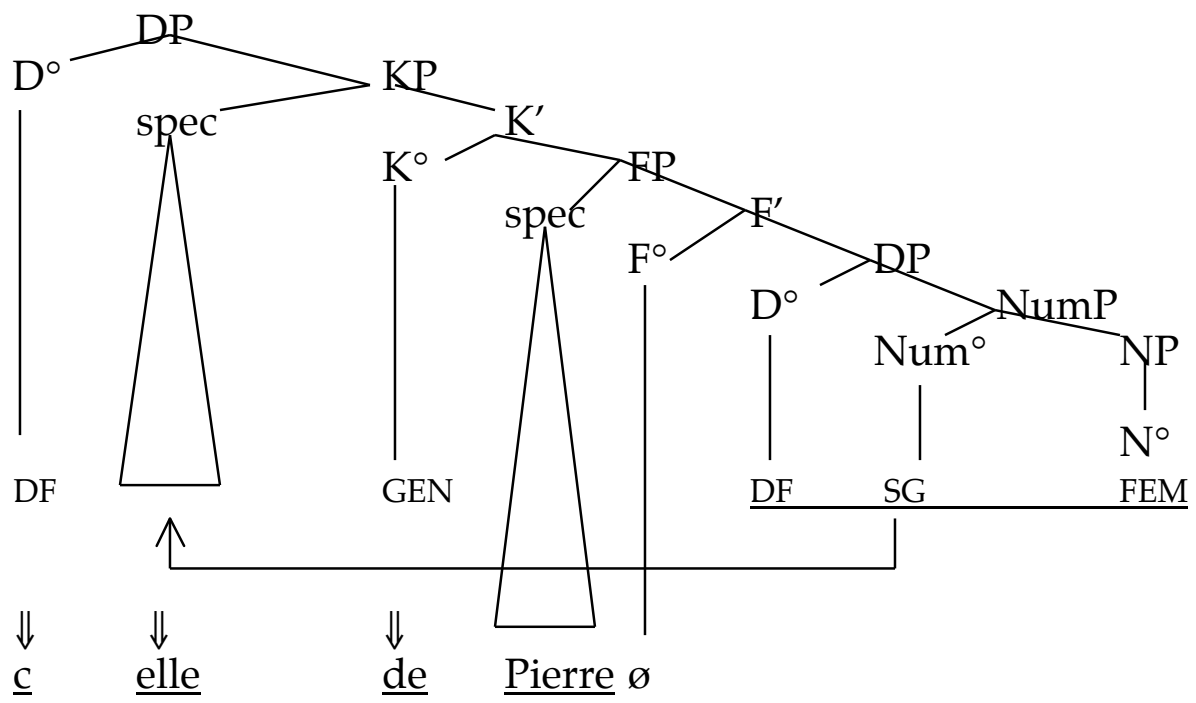

\section{Lexical subjects vs. Person inflection}

In $\left(7^{\prime}\right)$, the pronominal possessor occurs to the left of the Possessee, which suggests that the Possessee has not been relativized. Now, why would it be the case that the Possessee is relativized when the Possessor is lexical, but not when the Possessor is pronominal?

I assume, as did Authier (1992), that the person feature which characterizes such French possessive DPs as ( $\left.7^{\prime} \mathrm{b} 2\right)$ (sa boite), is, crucially generated not in the subject position, but in the F head, from which it identifies the subject:

\footnotetext{
${ }^{5}$ The VP-shell idea (Larson 1988) is ignored here for lack of space, and the structure of the inflectional domain is, for similar reasons, simplified.
} 
(13) sa boîte

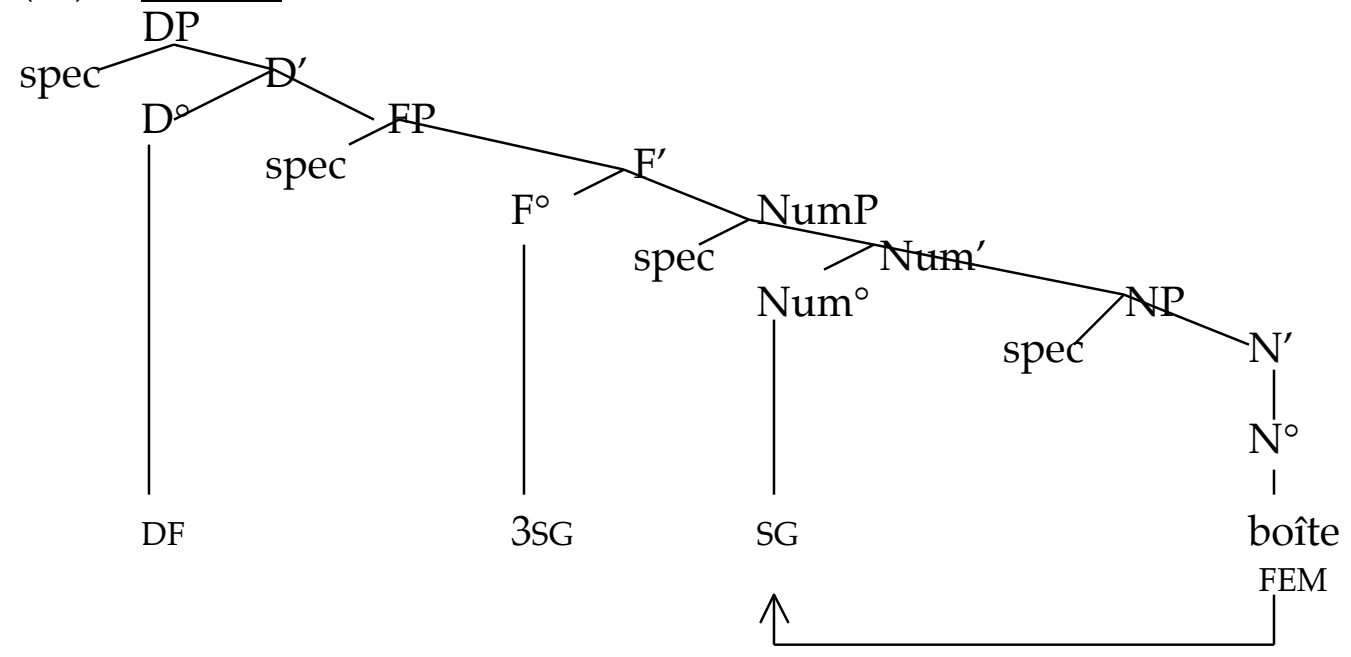

\section{Morphology :}

Phonology

3SG-DF-FEM -SG boîte-FEM-SG

$\begin{array}{llllcl}\Downarrow & \Downarrow & \Downarrow & \Downarrow & \text { b } & \Downarrow \\ \underline{\mathrm{S}} & \varnothing & \underline{\mathrm{a}} & \varnothing & \text { bwat } & \varnothing\end{array}$

I assume as above that $\mathrm{N}$ raises to Num in Morphology. Furthermore, the person feature generated in the $\mathrm{F}$ head adjoins in Morphology to the [+definite] feature generated in the D-head, while the gender and number features originating in the $\mathrm{N}$ and Number heads regularly percolate up to the definite D-head.

The morphological adjunction of [person] to [+definite] is, crucially, obligatory whenever possible. In other words, the person feature is spelt out as a clitic whenever possible; this generalization extends to all cases of cliticization in French thus, since the clitic is available in (14a/14'a), it must be chosen over the nonclitic, hence the ill-formedness of $\left(14 b / 14^{\prime} b\right)$ :
(14)a. Je le regarde.
b. *Je regarde lui.
'I am watching \{it/him\}.'
(14')a. J'ai trouvé sa boîte.
b. 'J'ai trouvé la boîte de lui. 'I found \{its/his\} box.'

The adjunction of [person] to [+definite] resulting in 'possessive determiners' seems to have settled in Middle French. The morphological adjunction of one functional feature to another is quite commonly observed throughout languages (e.g Person commonly adjoins to Tense or Tense to Person, in finite clauses, Person may adjoin to Number, Number to Definiteness, Definiteness to Case, etc.). The analysis considered in (13) brings out a symmetry between nominal predications (possessive DPs) and tensed predications, since there too a person feature identifying the subject may be assumed to be generated in $\mathrm{F}^{\circ}$.

I am assuming with, e.g., Harris (1978), Lambrecht (1981), Hulk (1986, 1991), Zribi-Hertz (1994), Jakubowicz \& Rigaut (1997), and Auger (1995), that the nominative personal pronouns of Modern French have become inflectional elements, i.e. are no longer generated in the subject position, but in a functional head, the one I have been calling F. The data are tricky to describe because Standard French is commonly equated with written French, which differs in various important respects 
from the spoken (which doesn't mean 'substandard') language. Person inflection is one among several properties which are expressed differently in Spoken and Written French. In Written French, (15c) may only be licensed as a left-dislocation, whereas in Spoken French, (16a) is licensed with no dislocation :

(15) Written French
a. Les enfants aiment le chocolat.
'(The) children (Mpl) like chocolate.'
b. Ils aiment le chocolat.
'They (Mpl) like chocolate.'
c. Les enfants * (,) ils aiment le chocolat.
lit. '(The) children (,) they like chocolate.'
d. $\quad$ *Tout le monde (,) il aime le chocolat.
lit. 'Everyone (,) they like chocolate.'

(16) Spoken (Parisian) French
a. Les enfants ils aiment le chocolat. [lezãfã izemla $\int$ okola]
b. ?Tout le monde il aime le chocolat. [tulmõd ilemləokola]
(socially neutral)
(substandard)

French nominative clitics have been developing from the subject status they inherited from Latin, towards the situation exemplified by (16). I assume, in the spirit of Givón's (1976) general hypothesis, that this evolution must have proceeded in three steps, described in (17) :

$\underline{\text { stage } 1}$ Nominative pronouns are generated in subject position; hence, they cannot combine with a subject, only with a dislocated topic, as shown by $(15 c, d)$. Finite verbs bear overt person-number endings generated in $\mathrm{F}^{\circ}$, which stand as agreement markers.

stage 2 Nominative pronouns are reidentified as inflection morphemes, generated in $\mathrm{F}^{\circ}$, making up for the phonetic impoverishment of consonantal personal endings on finite verbs (e.g. the person-number ending spelt $\underline{\mathrm{nt}}$ on aiment, in (15)).

The nominative pronouns of stage 2 have become inflectional elements while remaining argument markers, in the sense of Auger (1995), hence, they cannot combine with a lexical subject.

stage 3 Inflectional subject markers become agreement markers and hence acquire the ability to combine with a lexical subject: first, with a referential (topical) subject, as in (16a), then with any subject, whether or not referential, cf. (16b).

Under this analysis, I assume that Modern Parisian French is now moving from stage 2 to stage 3. The crucial point is that the distinction between argumental and inflectional person morphemes is independent from the distinction between argument and agreement inflectional markers, a point very clearly made by Auger (1995). A person feature may occur as an inflectional element and nevertheless stand as an argument marker, in which case it cannot cooccur in its local domain with the argument it serves to identify (see also Miller 1992). 
If this line of analysis is correct, French possessive DPs involving a pronominal possessor are symmetrical with French finite clauses involving a pronominal subject. In both cases, the person morpheme is an inflectional element, which standardly still behaves as an argument, rather than as an agreement, marker:
a. Pierre il est parti.
( ${ }^{*}$ in Standard French; OK in spoken French)
b. J'ai vu [Pierre son livre]. (*in Standard French; OK in some varieties of French)

\section{Possessive DPs with anaphoric NPs: French personal adjectives}

The adjunction of [person] to [+definite] explicited in (13) cannot occur in one case: when NP is phonetically null - and correlatively read as discourse-anaphoric. Null discourse-anaphoric NPs are quite common throughout languages, they occur for instance in English (cf. (19), but they similarly do so in, e.g., Fang, Bete, various creoles, etc. :

(19) a. I like this $\left[\right.$ box $\left._{z}\right]$, but I prefer [John-s $\left.\left[\varnothing_{z}\right]\right]$.

b I like this $\left[\right.$ box $\left._{z}\right]$, but I prefer $\left[\begin{array}{ll}\text { hi } & -\mathrm{s}\left[\varnothing_{z}\right.\end{array}\right]$.

In the French analogue of (19a), (9'a), I argued that the Possessee is relativized and nonnull (cf. (12). In the French analogue of (19b), (9'b), repeated under (20b), the Possessee is null and no relativization occurs :
a. Je préfère sa boîte.
'I prefer his box.'
b. Je préfère la sienne ø.
'I prefer his ø.'

The class of cases exemplified by (20b) is the only one in Modern French which productively licenses the personal adjectives listed in (21):

(21) French personal adjectives (sketching a morphological analysis)

\begin{tabular}{|c|c|c|c|c|c|}
\hline & & [Msg] & [FEMsg] & [Mpl] & [FEMpl] \\
\hline $1 s g$ & $\mathbf{m}$ & -ien & -ienne & -iens & -iennes \\
\hline $2 \mathrm{sg}$ & $\mathbf{t}$ & & & & \\
\hline $3 s g$ & $\mathbf{s}$ & mien, tien, sien & $\begin{array}{l}\text { mienne,tienne, } \\
\text { sienne }\end{array}$ & $\begin{array}{c}\text { miens, tiens, } \\
\text { siens }\end{array}$ & $\begin{array}{l}\text { miennes, tiennes, } \\
\text { siennes }\end{array}$ \\
\hline $1 \mathrm{pl}$ & nô & & re & & es \\
\hline & & nôtı & & nôtr & vôtres \\
\hline & le(u) & & & & rs \\
\hline & & & & & ars \\
\hline
\end{tabular}

The occurrence of a personal adjective in (20b) is motivated by morphophonology alone. Sa in (20a) and la sienne in (20b) both spell out the same set of features, which I assume to be rooted in the same syntactic positions: [+definite] (in $\mathrm{D}^{\circ}$ ), 3sg $\left(\right.$ in $^{\circ}$ ), Feminine (in $\mathrm{N}^{\circ}$ or $\mathrm{n}^{\circ}$, cf. Kihm, this volume), [-plural] (in $\mathrm{Num}^{\circ}$ ). Sa and la sienne only differ in the way these features are distributed in Morphology and spelt out in Phonology. 
Should [person] adjoin to [+definite] in (20b), we would derive (22c), which is ill-formed for the same reason as $(22 \mathrm{a})$ and $(22 \mathrm{~b})$ - because the determiner in $\mathrm{D}^{\circ}$ is phonologically deficient (a leaner, in Zwicky's 1982 sense) and therefore requires some phonetically overt element to its right:

(22) a. *Je préfère la ø. (compare : Ie préfère la boîte)

lit. 'I prefer the ø.' 'I prefer the box.'

b. *Je préfère ceø. (compare : Je préfère ce livre) lit. 'I prefer this ø.'

c. *Je préfère sa ø. (compare : Je préfère sa boîte) lit. 'I prefer his/hers ø.' 'I prefer his/her box.'

To avoid the violation in (22c), the person feature is not adjoined to the definite determiner in (20b), and is realized as a nonclitic word - an adjective, the category which regularly licenses elliptical NPs in French :
a. Je préfère 1 -a s- ien -ne $\varnothing$.
I prefer DF-FEMsg 3sg-ADJ -FEMsg
'I prefer $\{$ hi / her $\}$ s ø.'
b. Je préfère 1 -a grand-e ø.
I prefer DF-FEMsg tall FEMsg
lit. 'I prefer the tall $\mathrm{FSG}^{\prime}{ }^{\prime}=$ 'I prefer the tall one.'

I propose to analyse $\underline{i e n}$ in sien, as a phonetic spell-out of the $\underline{a}^{\circ}$ head (the functional adjectival head), as shown in (24) :

(24) la sienne

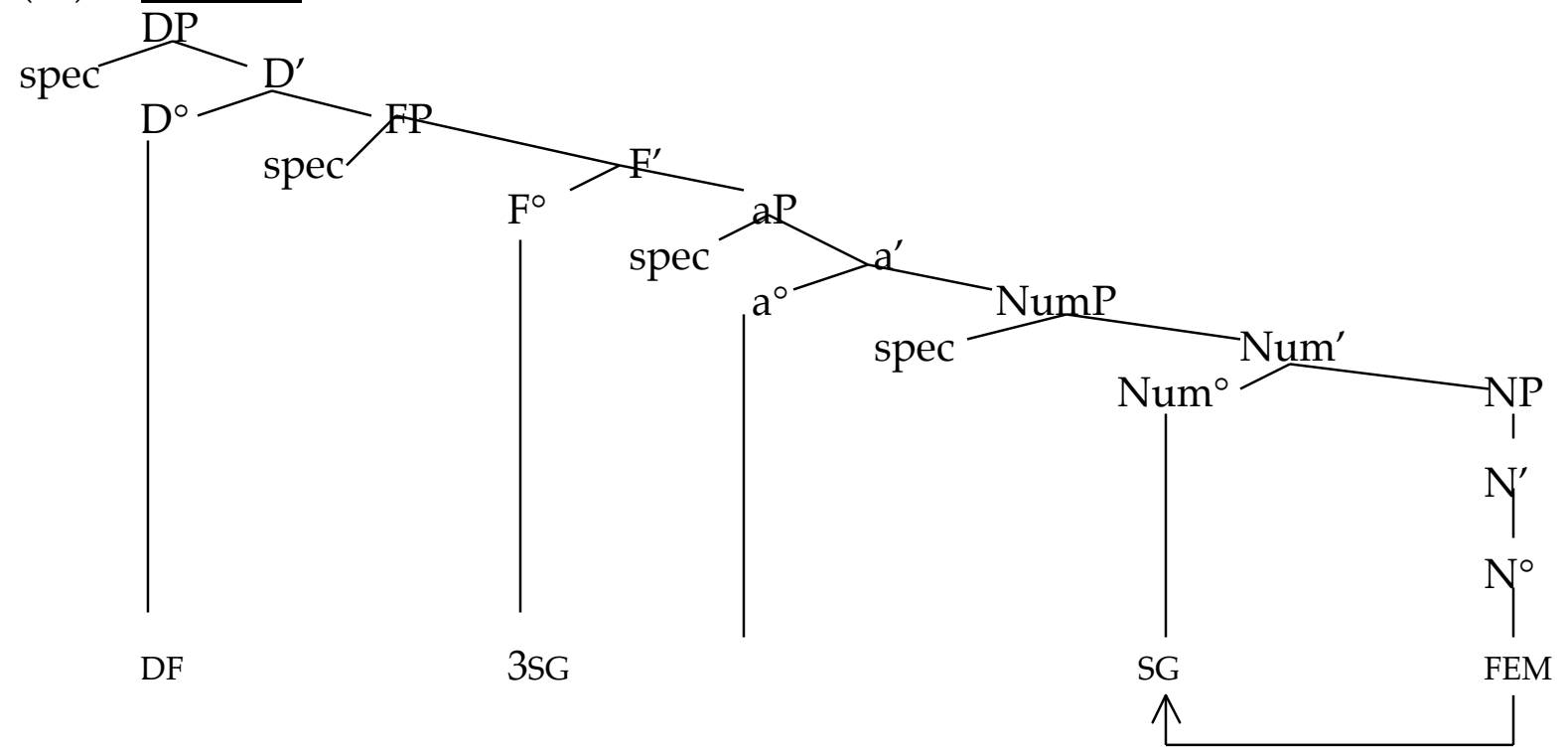

\section{Morphology :}

DF-FEM-SG

Phonology :

$\begin{array}{ccccccc}\Downarrow & \Downarrow & \Downarrow & \Downarrow & \Downarrow & \Downarrow & \Downarrow \\ 1 & \text { a } & \varnothing & \text { s } & \text { jen } & \text { jen } & \varnothing\end{array}$


Under this analysis, personal adjectives (sien), like personal definite determiners ( $\underline{\text { son }})$, are complex words made up of functional features generated in regular syntactic positions within the DP. One of these features is the person feature, generated in $\mathrm{F}^{\circ}$, an inflectional functional head closed to lexical information. The result is a pervasive asymmetry between pronominal possessors, which are identified inflectionally by a personal argument marker, and lexical possessors, which stand as full-fledged arguments, in subject position.

\section{Nonclitic inflectional pronouns}

The central assumption I am putting forward here is that the asymmetry between lexical and personal possessors which is observed in $\left(7^{\prime}\right)$ through $\left(9^{\prime}\right)$ does not stem out from the fact that personal subject markers are clitics (a phonological property), but from the fact that they are inflectional elements, a status from which both lexical words and phrases are banned. I am claiming that the distinction between subjects and subject markers is quite independent from the issue of clitichood: inflectional argument markers may a priori be spelt out phonologically as nonclitics. ${ }^{6}$

Crucial evidence in support of this assumption is provided by the contrast between (8) and $\left(8^{\prime}\right)$, repeated in the better-contextualized examples (25)-(26) :

\section{a. I found a box of John's in the kitchen. \\ b. (John...) I found a box of his in the kitchen. \\ c. I found a box of yours in the kitchen.}

$$
\begin{array}{lll}
\text { a. } & \text { 'J'ai trouvé une boîte à Jean dans la cuisine. } & (=(25 \mathrm{a})) \\
\text { b. } & \text { (Jean.....) J'ai trouvé une boîte à lui dans la cuisine. } & (=(25 \mathrm{~b})) \\
\text { c. } & \text { J'ai trouvé une boîte à toi dans la cuisine. } & (=(25 \mathrm{c}))
\end{array}
$$

These examples show that in English as in French, the Possessor may occur to the right of the Possessee in an indefinite DP. The two languages however differ in that a lexical and a pronominal possessor are equally licensed in (25), whereas in my dialect of French, only a pronominal possessor is licensed in (26). This contrast between a lexical and a pronominal possessor clearly recalls the ones discussed above. One way to express this similarity is to assume that the lexical possessor is disallowed in (26a) because the pronominal possessor of (26b) is generated (as other pronominal possessors) in the functional head $\mathrm{F}^{\circ}$, i.e. is an argument marker, rather than a fullfledged argument. In English, on the other hand, all possessors, both lexical and pronominal, are generated in an argument position (spec,FP), for Modern English does not make use of person inflection to identify arguments.

Adapting once more an idea of Kayne's (1993, 1994), I assume that the derivation of postnominal possessive DPs involves Possessee Raising, i.e. Possessee Relativization:

\footnotetext{
${ }^{6}$ Although my phrasing and terminology ('morphemes'!) do not strictly comply with Anderson's (1992) framework, I believe that the assumption put forward here is essentially compatible with his analysis of special clitics. According to this author (who follows in this respect Klavans 1985), (special) clitics are crucially characterized as elements which spell out phrasal inflectional features, phonetic deficiency standing as a frequent though not necessary property of this class. Under this view, the postnominal possessive pronoun lui in $(8$ 'b)/(26b) should be identified as what Anderson calls a 'clitic', although it does not behave phonologically as what Zwicky (1982) calls a 'leaner'. I prefer to define clitics as (a subclass of) leaners (true to etymology: Gr. klinein 'to lean'), which leads me to describe lui in (26b) as the nonclitic spell-out of a phrasal inflectional feature.
} 
(27) a box of John's / a box of his

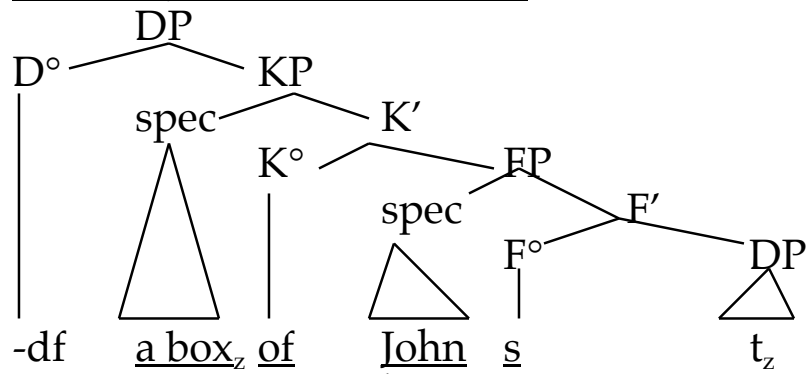

$\underline{\text { hi }}$

(28) une boîte à lui

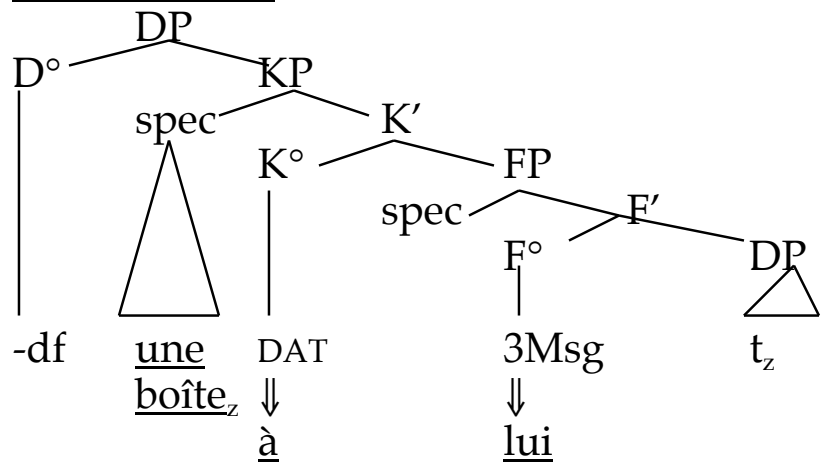

Under this analysis, lui, in une boîte à lui, spells out the same syntactic element as $\underline{\mathbf{s}}$, in sa boite and la sienne (diagrams (13) and (24)). The difference between lui in (28) and $\underline{s}$ in (13)/(24)) is purely morphophonological: in (28), the person feature in $\mathrm{F}^{\circ}$ cannot cliticize, since there is no definite feature for it to attach to; hence it is spelt out as a nonclitic morpheme (personal pronoun).

The complete distribution of lexical and functional possessors in my own dialect of French is given in (29): 
(29) Lexical and functional Possessors in definite and indefinite possessive DPs in Modern French : System 1 (my own)

\begin{tabular}{|c|c|c|c|c|c|c|c|}
\hline \multicolumn{4}{|c|}{ class-A nouns (e.g. ami 'friend') } & \multicolumn{4}{|c|}{ class-B nouns (e.g. boîte 'box') } \\
\hline \multicolumn{2}{|c|}{ definite DP } & \multicolumn{2}{|c|}{ indefinite DP } & \multicolumn{2}{|c|}{ definite DP } & \multicolumn{2}{|c|}{ indefinite DP } \\
\hline \multirow{2}{*}{$\begin{array}{l}\text { John's } \\
\text { friend }\end{array}$} & $\begin{array}{l}\text { l'ami de } \\
\text { Jean }\end{array}$ & \multirow{2}{*}{$\begin{array}{l}\text { a friend of } \\
\text { John's }\end{array}$} & $\begin{array}{l}\text { un ami } \\
\text { de Jean }\end{array}$ & \multirow{2}{*}{$\begin{array}{c}\text { John's } \\
\text { box }\end{array}$} & $\begin{array}{l}\text { la boîte } \\
\text { de Jean }\end{array}$ & \multirow{2}{*}{$\begin{array}{c}\text { a box of } \\
\text { John's }\end{array}$} & $\begin{array}{l}* \text { une boîte } \\
\text { de Jean }\end{array}$ \\
\hline & $\begin{array}{l}\text { *l'ami à } \\
\text { Jean }\end{array}$ & & $\begin{array}{c}\text { *un ami à } \\
\text { Jean }\end{array}$ & & $\begin{array}{c}\text { *la boîte à } \\
\text { Jean }\end{array}$ & & $\begin{array}{c}\text { *une boîte } \\
\text { à Jean }\end{array}$ \\
\hline \multirow{3}{*}{ his friend } & $\begin{array}{c}\text { *l'ami de } \\
\text { lui }\end{array}$ & \multirow{3}{*}{$\begin{array}{l}\text { a friend of } \\
\text { his }\end{array}$} & $\begin{array}{c}* \text { un ami } \\
\text { de lui }\end{array}$ & \multirow{3}{*}{ his box } & $\begin{array}{c}\text { *la boîte } \\
\text { de lui }\end{array}$ & \multirow{3}{*}{$\begin{array}{c}\text { a box of } \\
\text { his }\end{array}$} & $\begin{array}{c}\text { *une boîte } \\
\text { de lui }{ }^{7}\end{array}$ \\
\hline & $\begin{array}{l}\text { *l'ami à } \\
\text { lui }\end{array}$ & & $\begin{array}{c}\text { *un } \\
\text { son/sien } \\
\text { ami }\end{array}$ & & $\begin{array}{c}\text { *la } \\
\text { sa/sienne } \\
\text { boîte }\end{array}$ & & $\begin{array}{c}\text { *une } \\
\text { sa/sienne } \\
\text { boîte }\end{array}$ \\
\hline & son ami & & $\begin{array}{c}\text { un ami à } \\
\text { lui }\end{array}$ & & sa boîte & & $\begin{array}{c}\text { une boîte } \\
\text { à lui }\end{array}$ \\
\hline
\end{tabular}

This chart operates an initial distinction between two subclasses of nouns, labeled 'A' and 'B'. Type-A nouns, which we might characterize as those which are lexically endowed with an argument structure, include so-called relational nouns (e.g. ami 'friend', voisin 'neighbour', parent 'relative', cousin, etc.) and creation nouns (e.g. livre 'book', tableau 'painting', film, etc.). With type-A nouns, a de XP (Relatee, or Agent) argument is selected by the head-noun, in other words, is lexically licensed. With type-B nouns, which fail to have an argument structure in the lexicon and are typically illustrated by boîte 'box' in our examples, a de XP (Possessor) phrase must crucially be licensed by a definite article (1-a boite de Jean).

When it is spelt out by 1 - (i.e. when the Person feature does not adjoin to it), the definite feature in $\mathrm{D}$ must crucially pair up with the genitive feature in $\mathrm{K}$, resulting in l'ami de Jean/la boîte de Jean, not * $\mathbf{l}^{\prime}$ ami à Jean/ ${ }^{*}$ la boîte à Jean. When the $\mathrm{F}$ head contains a Person feature, it must adjoin to the [+definite] feature in $\mathrm{D}$, resulting in son ami/sa boîte, not ${ }^{*}{ }^{\prime}$ 'ami de lui/*la boîte de lui/ ${ }^{*}{ }^{\prime}$ ami à lui / ${ }^{*}$ la boîte à lui. ${ }^{*}$ Un son ami / *une sa boîte cannot be generated because personal articles (son/sa) crucially incorporate the marked value of the definite feature .

${ }^{*}$ Un sien ami / *une sienne boîte are no longer generated in Modern French because the clitic spell-out of the Person feature (s in the $3^{\text {rd }}$ person) is crucially correlated with the [+definite] feature, in this system: sa and la sienne appear today as two allomorphs of the same feature combination: +definite, person, gender, number. In former stages of French, where le sien ami and un sien ami were generated, possessive-marking was still done derivationally (by adjectives formed from person or nominal stems), rather than inflectionally (cf. Zribi-Hertz 1999).

\footnotetext{
${ }^{7}$ Une boîte de Jean could only be licensed if boîte 'box' was identified in the lexicon as a creation, Agentlicensing noun, similar to, e.g., tableau 'picture' (un tableau de Rembrandt 'a picture by Rembrandt'). Within an Agent de Phrase, lexical and functional Agents alternate freely: un tableau de Rembrandt 'a painting by Rembrandt', un tableau de lui 'a painting by him'; hence, une boîte de Picasso 'a box by Picasso', une boîte de lui 'a box by him'. In (29) and below, I treat boîte 'box' as a prototypical NON theta-assigner.
} 
An interesting question raised by table (29) is: why do we have a contrast in indefinite DPs between *un ami à Jean and un ami à lui, ${ }^{*}$ une boîte à Jean and une boîte à lui? There is no definite feature in $\mathrm{D}^{\circ}$ here, i.e. nothing the Person feature could cliticize to. Both une boîte à Jean and une boîte à lui could be derived from diagram (28).

My assumption is that the grammar of possessive DPs which is displayed in (29) is crucially centered on the complementary morphological marking of subject arguments and subject inflection. In definite possessive DPs, subject inflection correlates with clitichood (hence the ungrammaticality of $\left(14^{\prime} \mathrm{b}\right)$ ). In indefinite possessive DPs, the same complementarity is expressed by a different Case feature in K. Since the genitive feature (spelt out as de) occurs in l'ami de Jean/la boîte de Jean, hence, is associated with subject arguments, the dative feature is - complementarily restricted to subject inflection. The core constraint, in this system, is thus summarized by: $\underline{\text { de }>\text { Jean vs. à }>\text { lui. }}$

An obvious shortcoming of this grammar is that it fails to provide a means of generating a lexical subject in an indefinite possessive DP with a B-type N-head: there is no straightforward translation for a box of John's, in this system.

To my knowledge, this problem is dealt with by French speakers in three different ways, leading to three other competing grammars of possessive DPs, represented in (30), (31) and (32), and respectively labeled System 2, System 3, and System 4:

SYSTEM 2 (Tasmowski, c.p. ${ }^{8}$ ):

(30) a. la boîte de Jean

b. *la boîte à Jean

$\left(30^{\prime}\right)$ a. une boîte de Jean

c. *la boîte de lui

b. *une boîte à Jean

d. sa boîte

e. *la boîte à lui

c. * *une boîte de lui

d. une boîte à lui

\footnotetext{
${ }^{8}$ Liliane Tasmowski came up with the following example, which she regards as fine:

(i) Qu'est-ce que ce truc-là dans l'armoire ? Ah mais j'y suis, c'est un vieux tablier de Jean, qu'il portait pour dessiner quand il était enfant.

'What could be this thing in the cupboard? Oh yes, I remember now, it is an old pinafore of John's, which he used to wear as a child for art classes.'

My own judgment is that although (i) is indeed tolerable, there remains a sharp acceptability contrast between (iia) and (iib):

(ii) Qu'est-ce que c'est?

'What is this?'

a. C'est le tablier de Jean.

lit. 'It is the pinafore of John.' = 'It is John's pinafore.'

b. $\quad *$ C'est un tablier de Jean.

lit. 'It is a pinafore of John.'

What these data suggest is that System1-speakers may relax their grammar along the lines of System 2 whenever the discourse context strongly calls for a lexical possessor in an indefinite DP. This could be naturally described in terms of Optimality: (i) involves the violation of a constraint, but this violation (leading to System 2) is the mildest possible one, since it does not challenge the Ban on Dative Lexical Possessors, which is the backbone of System 1 (cf. fn. 9).
} 
SYSTEM 3 (Milner 1982)

(31) a. la boîte de Jean

b. *la boîte à Jean

c. *la boîte de lui

d. sa boîte

e. *la boîte à lui $\left(31^{\prime}\right)$
a. *une boîte de Jean
b. une boîte à Jean
c. *une boîte de lui
d. une boîte à lui

SYSTEM 4 (several varieties of spoken French, cf. Tremblay 1991)

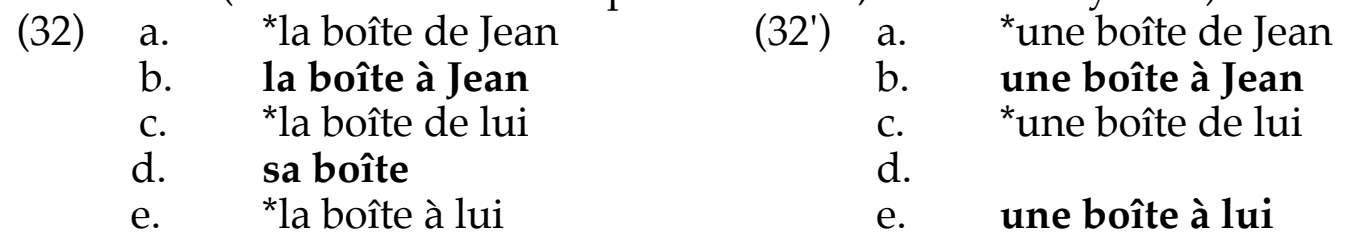

System 2 licenses lexical possessors in indefinite DPs by relaxing the

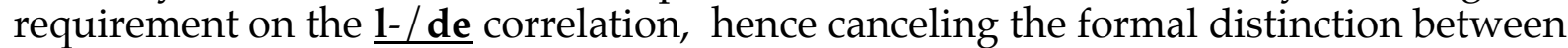
A-type and B-type nouns. In this system, de loses its force as an Agent theta-marker (see fn. 7), and the genitive becomes a means of licensing an argument with an Nhead regardless of the feature content of this $\mathrm{N}$. This is not a very costly move, since the same nondistinctiveness of de obtains in definite DPs (e.g. le tableau de Jean $=(i)$ 'Jean's painting' (ii) the painting by Jean'). Since System 2 furthermore preserves the morphological contrast between subject arguments and subject inflection, it departs from System 1 in the least radical way.

System 3 extends to lexical possessors in indefinite DPs the dative-Case strategy reserved for functional possessors in Systems 1 and 2. The contrast between (31b) ( ${ }^{*}$ la boîte à Jean) and (31'b) (une boîte à Jean), indicates that this system interprets the ill-formedness of $(31 b)^{9}$ as a Ban on the Definite/Dative correlation (la...à...), rather than as a Ban on Dative Lexical arguments (à Jean), contrasting in this respect with Systems 1 and 2. This change in the grammar breaks down the correlation between syntax and morphology achieved by Systems 1 and 2: in (31'), the syntactic distinction between subject arguments and subject inflection is not marked by morphology.

System 4 marks all postnominal possessors in the dative Case and thus does away with the genitive Case in possessive DPs; but to achieve this simplification, it fails to mark in morphology both the subject argument/subject inflection distinction ( overt in Systems 1 and 2), and the distincction between A-type and B-type nouns (overt in System 1).

It thus appears that System 1, which is maximally costly from a morphological perspective, and minimally satisfactory in terms of expressive power, nevertheless has its own justifications in terms of global economy. This accounts for the fact that it remains in active competition with the other systems in today's spoken French.

\footnotetext{
${ }^{9}$ The ban on *la boîte à Jean (> la boîte de Jean) undergoes a systematic and class-conscious external reinforcement in French educated circles. French speakers who grew up in such families have been trained to be sharply aware of the impropriety of *la boîte à Jean. What I am suggesting in this paper is that this external social judgment actually has linguistic motivations. However, the special social awareness linked to *la boîte à Jean must also play a part, albeit peripheral, in the striking resilience of System 1 in today's spoken French.
} 


\section{Conclusion}

The leading idea of this paper is that the regular asymmetry which characterizes Standard-French possessive DPs arises not from the (phonological) fact that subject pronouns are realized as clitics, in this language, but from a general syntactic contrast between subject arguments and subject inflection. A key contrast between personal morphemes and lexical DPs is that the former may be used to spell out inflectional features, whereas the latter may not. Inflectional features are frequently but in no way necessarily spelt out at PF as clitics or affixes, and such examples as une boîte à lui as produced by Systems 1 and 2, are evidence that inflectional person features may be spelt out as independent ('strong') pronouns.

Under the analysis proposed here, the contrasts between English and French exemplified by (7)-(8)-(9) essentially stem out from the fact that French, unlike English, makes use of person inflection to identify subjects. Attie and Hungarian similarly do so; but unlike those of French, the inflectional person features of Attie and Hungarian clearly stand as subject-agreement markers: in other words, these two languages are already firmly settled in stage 3, in the change pattern (17), while Modern French still has a foot in stage 2.

\section{References}

ABNEY, Steven. 1987. The English Noun Phrase in its sentential aspect. Unpublished diss., MIT.

ANDERSON, Stephen. 1992. A-morphous morphology, Cambridge University Press.

AUGER, Julie. 1995. 'Les clitiques pronominaux en français parlé informel : une approche morphologique.' Revue Québécoise de Linguistique 24-1 : 13-60..

AUTHIER, Jean-Marc. 1992. 'Is French a null subject language in the DP?' Probus 4.1: $1-16$

BORER, Hagit. 1996. 'The Construct in review.' In J. Lecarme, J. Lowenstamm, \& U. Shlonsky (eds.), Studies in Afroasiatic Grammar : 30-61, The Hague : North Holland Academic Graphics.

CHOMSKY, Noam. 1972. 'Remarks on nominalizations'. In Studies on semantics in generative grammar. La Haye : Mouton.

CHOMSKY, Noam. 1999. 'Derivation by phase', ms. MIT.

CINQUE, Guglielmo. 1994. 'On the evidence for partial N movement in the Romance DP', in G. Cinque \& al. (eds.), Paths towards Universal Grammar : studies in honor of Richard S. Kayne : 85-110, Washington D.C. : Georgetown University Press.

COLLINS, Chris. 1997. Local economy, Linguistic Inquiry Monograph 29, Cambridge, Mass : MIT Press.

GIORGI, Alessandra; Giuseppe LONGOBARDI. 1991. The syntax of noun phrases. Configurations, parameters and empty categories. Cambridge: CUP.

GIVON, Talmy. 1976. 'Topic, pronoun, and grammatical agreement'. In C. Li (ed.) Subject and Topic: 149-188, New York : Academic Press.

GODARD, Danièle. 1986. 'Les déterminants possessifs et les compléments de nom'. Langue française 72:102-122.

HARRIS, Martin. 1978. 'The evolution of French syntax : a comparative approach'. New York : Longman.

HULK, Aafke. 1986. 'Subject clitics and the pro-drop parameter.' In P. Coopmans, J. Bordelois \& B. Dotson-Smith (eds) Going Romance, Formal parameters of generative grammar II. Dordrecht, ICG Printing : 107-120. 
HULK, Aafke. 1991. 'Les pronoms clitiques sujets et la théorie linguitique.' Actes du XVIIIème congrès international de linguistique et de philologie romanes :504514.Tübingen : Niemeyer.

JAKUBOWICZ, Celia ; Catherine RIGAUT. 1997. 'L'acquisition des clitiques nominatifs en français.' In A. Zribi-Hertz (ed) Les pronoms : morphologie, syntaxe et typologie. Saint-Denis : Presses Universitaires de Vincennes.

KAYNE, Richard. 1993. 'Toward a modular theory of auxiliary selection'. Studia Linguistica 47: 3-31.

KAYNE, Richard. 1994. The antisymmetry of syntax. Cambridge, MA: MIT Press.

KLAVANS, Judith. 1985. 'The independence of syntax and phonology in cliticization'. Language 61 :95-120.

KNITTEL, Marie-Laurence. 1998. 'La structure morphosyntaxique des syntagmes nominaux possessivés du hongrois', in J. Guéron \& A. Zribi-Hertz (eds.), La grammaire de la possession : 83-128, Nanterre (France) : Publidix.

KUPFERMAN, Lucien. 1996a. 'Les génitifs : gouvernement d'antécédent et gouvernement thématique.' Langue française 109 : 104-125.

KUPFERMAN, Lucien. 1996b. 'Structure prédicat-argument des nominaux et relativisation.' Paper presented at the Upsala conference on predication.

LAMBRECHT, Knud. 1981. Topic, antitopic and verb agreement in non-standard French . Amsterdam : John Benjamins.

LARSON, Richard. 1988. 'On the double-object construction', Linguistic Inquiry 193 :335-392.

MILLER, Philip. 1992. Clitics and constituents in Phrase Structure Grammar. New York : Garland.

MILNER, Jean-Claude. 1982a. 'Les génitifs adnominaux en français'. Ordres et raisons de langue: 69-94. Paris: Seuil.

MILNER, Jean-Claude. 1982b. 'Du génitif possessif comme sujet syntaxique'. Ordres et raisons de langue: 95-122. Paris: Seuil.

MILNER, Jean-Claude. 1982c. 'De l'existence du sujet dans les groupes nominaux'. Ordres et raisons de langue: 123-139. Paris: Seuil.

MILSARK, Gary, 1977, 'Toward an explanation of certain peculiarities in the existential construction in English', Linguistic Analysis 3, pp. 1-30.

PAUL, Ileana. 1996. 'The Malagasy genitive', in M. Pearson \& I. Paul (eds.), The structure of Malagasy, vol. 1 : 76-91, UCLA Occasional Papers in Linguistics 17, Department of Linguistics, UCLA.

RITTER, Elizabeth. 1991. 'Two functional categories in noun phrases : evidence from Modern Hebrew', in S. Rothstein (ed.), Syntax and Semantics. Perspectives on Phrase Structure : Heads and Licensing : 37-62, New York : Academic Press.

SZABOLCSI, Anna. 1984. The possessor that ran away from home. The Linguistic Review 3:69-102.

SZABOLCSI, Anna. 1994. 'The Noun Phrase'. In The syntactic structure of Hungarian. Syntax \& Semantics 27 : 179-274. New York : Academic Press.

TREMBLAY, Mireille. 1991. Possession and datives. Binary branching from the lexicon to syntax. Unpublished Ph.D. diss., McGill.

VOSKUIL, Jan. 1993. 'Abstract Case and Malagasy.' Ms., Université McGill.

ZRIBI-HERTZ, Anne. 1994.'The syntax of nominative clitics in Standard and Advanced French'. In G. Cinque \& al., Paths towards Universal Grammar : studies in honor of Richard S. Kayne : 453-472, Washington D.C. : Georgetown University Press.

ZRIBI-HERTZ, Anne. 1997. 'On the dual nature of the English possessive marker in Modern English'. Journal of Linguistics 33-2. 
ZRIBI-HERTZ, Anne. 1998. 'Les syntagmes nominaux possessifs en français moderne : syntaxe et morphologie', in J. Guéron \& A. Zribi-Hertz (eds.), La grammaire de la possession : 129-166, Nanterre (France) : Publidix.

ZRIBI-HERTZ, Anne. 1999. 'Le système des possessifs en français moderne.' Langue française 122 : 7-29.

ZRIBI-HERTZ, Anne ; Charlemagne ADOPO. 1992. 'The syntax of Attie pronominals.' The Linguistic Review 9:69-108.

ZWICKY, Arnold. 1982. 'Stranded to and phonological phrasing in English.' Linguistics $20: 3-57$. 